\title{
Evaluation Of In Vitro Anticancer Activity of Crude Extracts Obtained from Two Bacterial Strains Isolated from Kodiyampalayam, Tamil Nadu
}

\author{
S Satheesh Kumar, Uma C, Illiyas Maqbool Malla, K Muthulakshmi, P \\ Sivagurunathan
}

\begin{abstract}
Extracts of natural products, especially microorganisms, have been a valuable source of various molecules in many drug discovery efforts and led to the discovery of many important drugs. The identification of microbial strains with promising biological activities and the purification of biomolecules responsible for activities led to the discovery of many biologically active molecules.Crude extracts of two marine bacterial isolates isolated from marine sediment samples, were studied for their in vitro anticancer activity against human oral squamous carcinoma (KB) cell line. Morphological studies and biochemical tests of the two bacterial extracts were also carried out. Cytotoxic, intracellular ROS, nuclear staining and apoptotic morphological alteration studies were carried out to assess the anticancer potential of each extract. The crude ethyl acetate extract of KP-9 isolate showed promising results by MTT assay with IC50 as low as $7.9 \mu \mathrm{g} / \mathrm{ml}$ while as $\mathrm{KP}-7$ showed an IC50 value of $21.1 \mu \mathrm{g} / \mathrm{ml}$ in $\mathrm{KB}$ cells. The crude extract of KP-9 augmented higher levels of ROS and displayed higher potential by inducing higher levels of nuclear and morphological alterations when compared with KP-7 bacterial extract in KB cells.
\end{abstract}

Keywords: Anticancer activity, Microbial extracts, Cytotoxicity, ROS.

\section{INTRODUCTION}

Over the past 75 years, compounds derived from natural products have led to the discovery of many drugs for the treatment of many human diseases [17]. Natural products are chemical compounds derived from organisms, for example plants, animals and microorganisms. Can be defined as chemical compounds isolated or derived from organisms as primary or secondary metabolites. Through the use of advanced techniques in many detection programs, the detection rate of natural compounds exceeded one million sofa [30]. Of which 22,500 are biologically active compounds extracted from microbes, $45 \%$ are

produced by actinobacter, $38 \%$ by fungi and $17 \%$ by unicellular bacteria [10]. The oceans cover more than $70 \%$ of the Earth's surface, and little is known about the microbial

Revised Manuscript Received on October 25, 2019.

Satheesh Kumar ${ }^{\mathrm{a}}$, Uma $\mathbf{C}^{\mathrm{a}}$, K Muthulakshmi $^{\mathrm{a}}$, P Sivagurunathan $^{\mathrm{a}^{*}}$, Department of Microbiology, Annamalai University. Annamalainagar-608002.

Corresponding author Email: sivaguru1981@gmail.com.

Illiyas Maqbool Malla ${ }^{\mathbf{b}}$, Department of Biochemistry \& Biotechnology, Annamalai University. Annamalainagar-608002. diversity of marine sediments, an inexhaustible resource that has not been fully exploited. Severe marine organisms act as a valuable natural source of new products such as antibiotics, antineoplastic agents and other therapeutic substances [2].Secondary microbial metabolites are known as one of the enormous reservoirs of natural chemical diversity with active biological activity [6].

Most bacterial secondary metabolites are created by a unique multi-step biological process with specific enzymes for each complex structure formation. Their coding genes are usually assembled within the organism's genome and biosynthesis precursors are obtained from primary metabolites.

Research on natural biologically active compounds that can act as antioxidant and anti-cancer agents has gained interest in industry and in scientific research. The harmful nature of reactive oxygen species (ROS) produced during oxidation processes, and the harmful nature of synthetic antioxidants such as butyl hydroxyanol (BHA) and butyl hydroxytoloin (BHT) and increased microorganism resistance to synthetic drugs have contributed to the increased search for new antibiotics. Biologically active ingredients of natural origin [29].

The escalating knowledge of reactive oxygen species (ROS) has revolutionized medicine [26]. ROS contributes to cardiovascular diseases and cancer [3,18] and could cause immune system depletion [18,28]. A typical antioxidant donates an electron to a free radical thus neutralizing it [19] and often bind to metals [5].Synthetic antioxidants cause negative health effects [11]. Reports have recommended to replace synthetic antioxidants with natural ones [5,32] to control formation of free radicals [8]. The most common natural antioxidants are antioxidative enzymes [16] whereas others are well represented in different spices and herbs [20].

From pulmonary disorders to autoimmune diseases to cancer (the focus of this review), MMPs have been found to directly contribute to disease progression [12,31]. MMPs are present in nearly all human cancers; they can be expressed by healthy fibroblasts in the adjacent stroma, cancer-associated fibroblasts, and/or by non-fibroblastic cancer cells. This is of great significance, as MMPs can influence the tumor environment by promoting angiogenesis, tumor growth, and

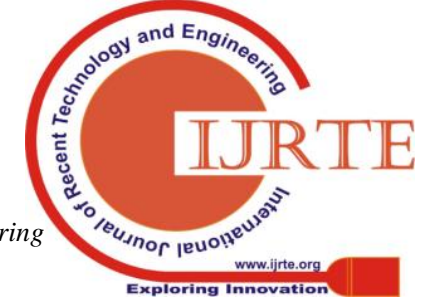


metastasis.[4,22].Accordingly, MMP expression is tied to tumor aggressiveness, stage, and patient prognosis [21,37].

Transcription of MMPs is tightly regulated and expression is generally very low. Further regulation of MMP activity occurs by post-translational modification, production of the enzymes as zymogens requiring activation, and coexpression of tissue inhibitors of metalloproteinases (TIMPs)[7,34].Dysregulation of any of these regulatory mechanisms during pathological conditions may contribute to worsening of disease[34]. Increased expression of MMPs is correlated to increased cancer cell proliferation and an increase in tumor size. Overexpression of MMP-3 in the phenotypically normal murine mammary epithelial cell line, SCp2, using a tetracycline inducible system injected into surgically cleared mammary tissue has been shown to be sufficient to induce spontaneous disease progression [33].Similarly, MMP-2 levels detected in cancer tissue are significantly correlated to larger tumor size [25].Several MMPs have been shown to drive cell migration and invasion through the basement membrane. Sequence-specific silencing of MMP-14 alone significantly attenuates both migration and invasion of cancer cells in vitro[35].

\section{MATERIALS AND METHODS}

\section{A. Isolation of bacterial strains}

Samples were taken at the depth of $2 \mathrm{~cm}$ inside the marine sediment. Samples were collected in sterile polypropylene tubes and immediately transferred to the lab for further analysis. The soil samples were suspended in sterile autoclaved nutrient broth and incubated at $37{ }^{\circ} \mathrm{C}$ overnight. The broth culture was

serially diluted with sterile phosphate buffered saline (PBS) and plated on nutrient agar. The plates were then incubated for $24 \mathrm{~h}$ at $37^{\circ} \mathrm{C}$. The pure colonies of each isolate were then isolated and used for further analysis.

\section{B.Cell morphology and biochemical tests}

The morphological and biochemical characterization was carried out for the two bacterial strains (KP-7 and KP-9). The morphological characteristics like colony colour, shape and forming of the bacterial strains was studied by Grams staining and microscopic examinations of each strain. The biochemical characterization studies of each strain (KP-7 and KP-9) included indole test, methyl red test, Voges-Proskauer (VP) test, Citrate reduction test, Triple Sugar Iron (TSI)test, catalase and oxidase test was carried out.

\section{Cell line and culture}

The human oral squamous carcinoma $(\mathrm{KB})$ cell line was obtained from cell repository of National Centre for Cell Sciences, (NCCS) Pune, India. KB cells were cultured in Dolbico's Eagle's minimal essential medium (DMEM, Himedia) with $2.0 \mathrm{mM}$ of L-glutamine, $1.5 \mathrm{~g} / \mathrm{l}$ of $\mathrm{NaHCO}_{3}$, $0.1 \mathrm{mM}$ of nonessential amino acids, $1.0 \mathrm{mM}$ of sodium pyruvate, and supplemented to contain $10 \%(\mathrm{v} / \mathrm{v})$ fetal bovine serum (FBS, Himedia). Cells were grown at $37{ }^{\circ} \mathrm{C}$ and $5 \%$ $\mathrm{CO}_{2}$ in humidified air.

\section{MTT assay}

A total of $106 \times 10^{7}$ cells were seeded into 96-well plates and exposed to different bacterial extracts for 1 hour. The cytotoxicity of the bacterial extracts was assessed by the MTT assay according to the procedure used by Igarashi and Miyazawa [18]. MTT $(50 \mu \mathrm{l})$ was added to the treated wells. The plate was incubated at $37{ }^{\circ} \mathrm{C}$ for 3 hours with mild shaking. The cells were then resuspended in $200 \mu \mathrm{L}$ of DMSO for $30 \mathrm{~min}$ in the dark. The absorbance was read at $650 \mathrm{~nm}$, in a microtiter plate reader (Anthos, Germany).

\section{E. Determination of ROS by DCFH-DA dye method}

Intracellular ROS was determined by the method of [23]. KB cells ( $1 \times 10^{4}$ cells) were seeded in 96-well plate and exposed to different concentrations $(1,5$ and $10 \mu \mathrm{g} / \mathrm{ml})$ of bacterial extract $(50,100$, and $200 \mathrm{~m} \mathrm{M})$ for $24 \mathrm{~h}$. After exposure, cells were incubated with 2,7-dichlorodihydro fluorescein diacetate (DCFH-DA) $(10 \mathrm{mM})$ for $30 \mathrm{~min}$ at 37 ${ }^{\circ} \mathrm{C}$. The cells were washed twice with PBS and resuspended in $1 \mathrm{ml}$ of PBS. Fluorescence intensity was measured (excitation/emission at $495 \mathrm{~nm} / 529 \mathrm{~nm}$ ). Cells were also observed under fluorescent microscope (Nikon ECLIPSE Ti-S, Japan).

\section{F. Determination of apoptosis by AO/EtBr dual staining}

$\mathrm{AO} / \mathrm{EtBr}$ method was carried to determine the apoptosis according to the method of [9]. KB cells were seeded in a 12-well plate for overnight at $37{ }^{\circ} \mathrm{C}$. The cells were then treated with different concentrations $(1,5$ and $10 \mu \mathrm{g} / \mathrm{ml})$ of bacterial extracts for $24 \mathrm{~h}$. The treated cells were then incubated for $60 \mathrm{~min}$ with $10 \mu \mathrm{L}$ of $\operatorname{EtBr}(5 \mathrm{mg} / \mathrm{mL})$. The cells were washed twice with PBS and resuspended in PBS. Cells were then observed for apoptosis under a fluorescence microscope (Nikon, Japan) (400 X) magnification. The ratios of apoptotic cells to normal cells were calculated and expressed as percentage apoptosis for each treatment group.

\section{G. DAPI assay}

The apoptotic effect of the bacterial extracts was analyzed by fluorescent nuclear dye DAPI according to the method of [1]. KB cells were seeded in a 12-well plate and treated with different concentrations $(1,5$ and $10 \mu \mathrm{g} / \mathrm{ml})$ of bacterial extracts for $24 \mathrm{~h}$. Cells were then stained with DAPI dye for 1 hour, washed twice with PBS and observed under blue filter on a fluorescent microscope (Nikon ECLIPSE Ti-S, Japan).

\section{H. Statistical analysis}

Each experiment was performed at least six times $(n=6)$ and the results are presented as the mean \pm SD. The statistical analyses were performed using GraphPad Prism 5 software (GraphPad Software Inc, La Jolla, CA). Graphs are prepared using Microsoft Office Excel 2007. The $\mathrm{IC}_{50}$ values were calculated using the linear regression analysis.

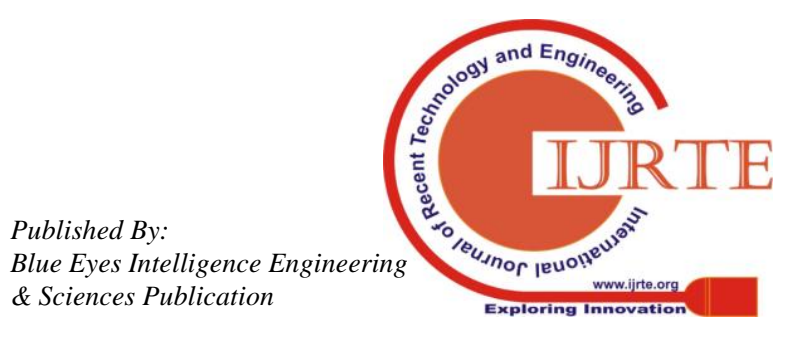




\section{RESULTS}

A. Morphological and biochemical characterization of isolates

The morphological and biochemical characterization was carried out for the two bacterial strains (KP-7 and KP-9). The results are given in Figure 1 and Figure 2; Table. 1.

Figure1. Isolation of two isolates (KP-7 and KP-9) from marine sediment samples.
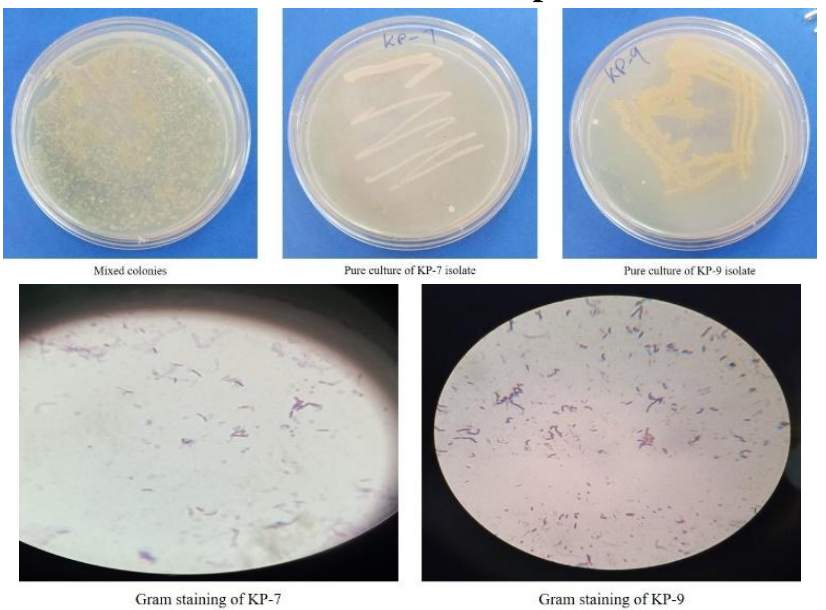

Figure 2. Isolation of two isolates (KP-7 and KP-9) from marine sediment samples.

Table 1: Biochemical and morphological characteristics of the bacterial strains (KP-7 and KP-9) isolated from the marinesamples.

\begin{tabular}{|l|l|l|}
\hline Biochemical test & KP-7 & KP-9 \\
\hline Indole & - & - \\
\hline Methyl Red & - & - \\
\hline VP & - & - \\
\hline Citrate & + & + \\
\hline Triple Sugar iron & Acid bud & Acid bud \\
& Alkaline slant & Alkaline slant \\
\hline Catalase & - & + \\
\hline Oxidase & - & + \\
\hline Morphological characteristics & \\
\hline Colony colour & \multicolumn{2}{|l|}{} \\
\hline Cell morphology & White & Yellow \\
\hline Forming & Rod shaped & Rod shaped \\
\hline & Chain & Chain \\
\hline
\end{tabular}

\section{B.Effect of bacterial extracts on cell viability of $\mathrm{KB}$ cells}

We observed a considerable decrease in the cell viability of $\mathrm{KB}$ cells when treated with different concentrations of bacterial extracts. However, cell viability was found to be decreased more in the cells treated with extract of KP-9 bacterial strain. The $\mathrm{IC}_{50}$ values of KP-7 and KP-9 bacterial extracts were measured to be $21.1 \mu \mathrm{g} / \mathrm{ml}$ and $7.9 \mu \mathrm{g} / \mathrm{ml}$, respectively (Figure. 3 ). The results obtained from this assay clearly validate that the extracts obtained from
KP-7 and KP-9 bacterial strains possess excellent cytotoxic activity against $\mathrm{KB}$ cells.

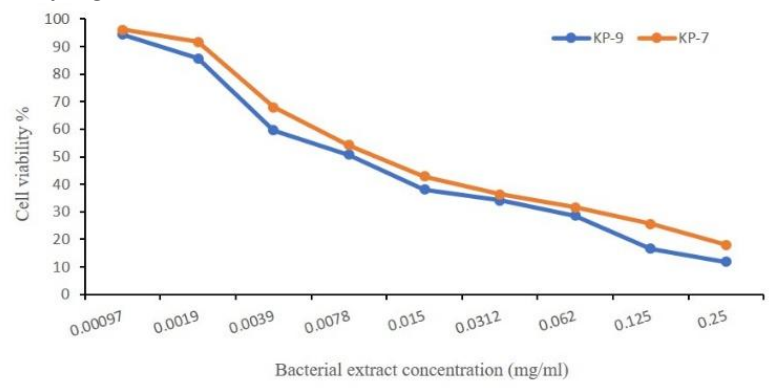

Figure. 3. Cytotoxicity of extracts from two different bacterial strains (KP-7 and KP-9) in KB cells. Cells were treated with different concentrations of KP-7 and KP-9 bacterial extracts for $24 \mathrm{~h}$ at $37{ }^{\circ} \mathrm{C}$. Cell viability was determined, and results were given as mean and $\pm \mathrm{SD}$ of six separate experiments.

\section{C.Effect of bacterial extracts on intracellular ROS in KB cells}

We observed a significant increase in the intracellular ROS formation in KB cells when treated with different concentrations of bacterial extracts (Figure. 4). The KP-9 bacterial extract was profoundly able to induce higher levels of intracellular ROS in KB cells when compared to treatment with KP-7 bacterial extract. The increase in the intracellular ROS in KB cells followed a concentration dependent manner. The results obtained from this assay prove that the KP-7 and KP-9 bacterial extracts have the potential to induce the formation of intracellular ROS in KB cells.
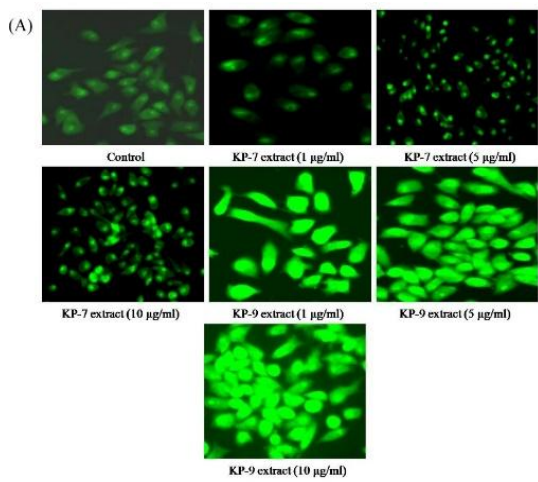

(B)

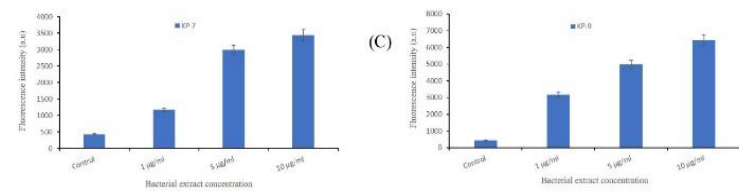

Figure. 4. effect of extracts from two different bacterial strains (KP-7 and KP-9) on intracellular ROS generation in $\mathrm{KB}$ cells. Cells were treated with different concentrations of $\mathrm{KP}-7$ and KP-9 bacterial extracts for $24 \mathrm{~h}$ at $37^{\circ} \mathrm{C}$. Cells were observed (A) microscopically and for fluorescence intensity under green filter (B) and (C). Results are given as mean and \pm $\mathrm{SD}$ of six separate experiments.

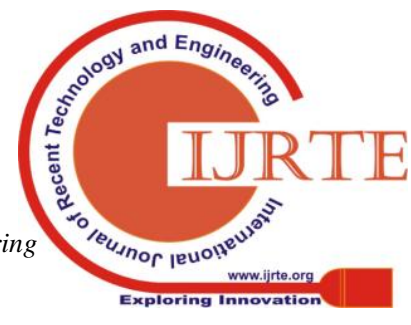




\section{Effect of bacterial extracts on cellular apoptosis in KB} cells

We found that the KP-7 and KP-9 bacterial extract treatments were able to induce irregular nuclear morphology in $\mathrm{KB}$ cells which is a hallmark of cell apoptosis.

The levels of apoptosis followed a concentration dependent manner in KB cells. While the KP-9 bacterial extract induced higher levels of cellular apoptosis, mild levels of apoptosis were observed with the increased concentrations of KP-7 bacterial extract treatments in KB cells (Figure. 5).

\section{E. Effect of bacterial extracts on the nuclear alterations in KB cells}

We observed that the KP-7 and KP-9 bacterial extracts treatments induced significant levels of nuclear alterations in KB cells. Treatment with extract obtained from KP-9 showed more potential to induce nuclear alterations in $\mathrm{KB}$ cells when compared to the KP-7 bacterial extract treatment (Figure. 6). Our results from this assay show that extracts obtained from KP-9 and KP-7 bacterial strains possess efficient potential to induce nuclear alterations in $\mathrm{KB}$ cells.
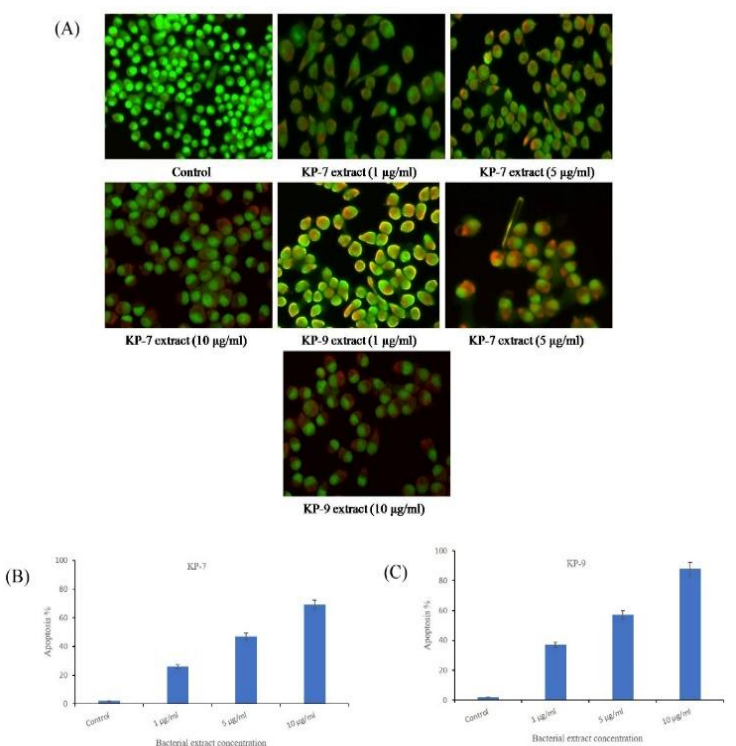

Figure. 5. Effect of bacterial extracts (KP-7 and KP-9) on apoptosis in KB-cells. Cells were treated with different concentrations of KP-7 and KP-9 bacterial extracts for $24 \mathrm{~h}$ at

$37^{\circ} \mathrm{C}$. Cells were observed (A) microscopically and for fluorescence intensity (B) and (C) under blue filter. Results are given as mean and \pm SD of six separate experiments.
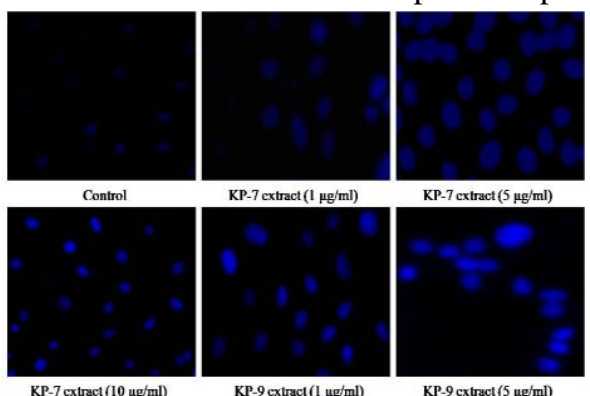

KP-7 extract $(1$ rg/ml)

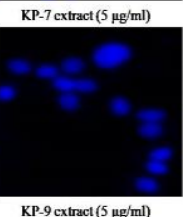

KP-7 extract $(10 \mu g / m l)$

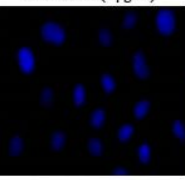

KP-9 extract $(1 \mu \mathrm{g} / \mathrm{ml})$

KP-9 cxtracl (5 $\mu \mathrm{g} / \mathrm{ml})$

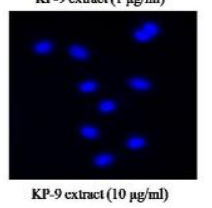

Figure. 6. Effect of bacterial extracts (KP-7 and KP-9) on nuclear alterations in KB-cells. Cells were treated with different concentrations of KP-7 and KP-9 bacterial extracts for $24 \mathrm{~h}$ at $37{ }^{\circ} \mathrm{C}$. Cells were observed (A) microscopically and for fluorescence intensity (B) and (C) under blue filter. Results are given as mean and \pm SD of six separate experiments.

\section{DISCUSSIONS}

Our study represents the first anticancer report of the crude extract of two bacterial strains isolated from the marine sediments. The results from the current study showed that the crude extracts of KP-7 and KP-9, exhibited potential anticancer activity in KB cells. KP-9 bacterial extract showed more potential activity when compared to KP-7 bacterial strain. By combining the knowledge of different anticancer assays and assessment of anticancer parameters in the present study, it can be asserted that the investigated bacterial strains (KP-7 and KP-9) could be viable source for natural anticancer agents. The current study also provided evidence that the extracts of the two bacterial strains are the source of natural therapeutic agents, which can be accounted for the traditional uses in the prevention of cancer and health preservation. This study provides supportive data for future investigations that will lead to their use in cancer therapy. Purification of the active components present in the crude extract of the two bacterial extracts and detailed pathway analysis could be performed to understand their basic mechanism of action. The reliable criteria for judging the value of anticancer drugs are prolongation of lifespan, decrease of WBC from blood and decrease of tumor volume. The reduction in cell viability showed that the crude extracts plays a direct role in killing tumor cells and enhance the curative effect tumor chemotherapy. At high concentration, ROS can produce oxidative damage, especially in the DNA, causing cell death [27]. The present study showed that crude extracts significantly elevated intracellular ROS levels which followed a concentration dependent manner. While the KP-7 bacterial crude extract exhibited a mild activity but KP-9 bacterial extract displayed significant activity in KB cells.

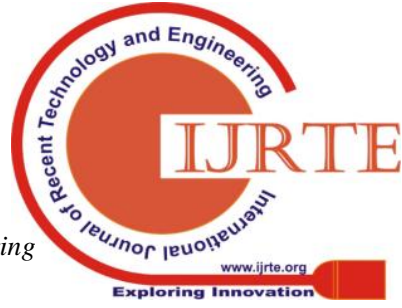


This theory forges the fundamental link between neoplasia and apoptosis, as exemplified by the ability of oncogenes including Myc, and tumor suppressors such as p53 to actively engage apoptosis.The ability of Myc to drive apoptosis in addition to providing a potent proliferative signal is interpreted as a failsafe mechanism to offset its oncogenic capacity [24]. Treatment with crude extracts significantly induced the apoptosis in KB cells. The KP-9 bacterial extract was noticed to be inducing more apoptosis when compared to KP-7 bacterial crude extract. This showed that bacterial extracts possess activity against proliferation of $\mathrm{KB}$ cells. Normal cells comprise an intact cell nucleus with a nonrandom spatial organization of chromosomes and genes. Such cell type-specific architecture can be altered in various diseases through impaired cell microenvironmental interactions leading to globulated and indented nuclear morphologies with defective nucleoli and other nuclear bodies [36] Increased nuclear alterations with bacterial (KP-7 and KP-9) crude extract treatments caused alterations in the nuclei and followed a concentration dependent fashion.

\section{CONCLUSION}

We propose that the crude extract of two bacterial extracts, KP-7 and KP-9, have significant antitumor activity. The present study demonstrates that the crude extract of KP-7 and KP-9 decreased the cell viability, increased the intracellular ROS levels, induced apoptosis and increased nuclear alterations in KB cells. The data suggest that crude extract of KP-7 and KP-9 possesses anticancer properties valuable for application in drug development strategies.

\section{REFERENCES}

1. Ahamad, M. S., Siddiqui, S., Jafri, A., Ahmad, S., Afzal, M., \& Arshad, M. (2014). Induction of apoptosis and antiproliferative activity of naringenin in human epidermoid carcinoma cell through ROS generation and cell cycle arrest. PloS one, 9(10), e110003.

2. Amador, M. L., Jimeno, J., Paz-Ares, L., Cortes-Funes, H., \& Hidalgo, M. (2003). Progress in the development and acquisition of anticancer agents from marine sources. Annals of Oncology, 14(11), 1607-1615.

3. Aruoma OI. Free radicals, antioxidants and international nutrition. Asia Pac J Clin Nutr. 1999.8:53-63.

4. Bhowmick NA, Neilson EG, Moses HL. Stromal fibroblasts in cancer initiation and progression. Nature. 2004.432:332e337.

5. Brewer MS. Natural antioxidants: sources, compounds, mechanisms of action, and potential applications. Compr Rev Food Sci Food Saf. 2011.10:221-47.

6. Bush, K., Macielag, M., 2000. New approaches in the treatment of bacterial infections. Curr. Opin. Chem. Biol. 4, 433-439.

7. Cerda-Costa N, Xavier Gomis-Ruth F. Architecture and function of metallopeptidase catalytic domains. Protein Sci. 2014. 23:123e144.

8. Chaudière J, Ferrari-Iliou R. Intracellular antioxidants: from chemical to biochemical mechanisms. Food Chem Toxicol. 1999.37:949-62.

9. Cohen, J. J. (1993). bronunol. Today, 14, 126-130.

10. Demain, A.L., Sa' nchez, S., 2009. Microbial drug discovery: 80 years of progress. J. Antibiot. 62, 5-16.

11. Ebrahimzadeh MA, Pourmorad F, Hafezi S. Antioxidant activities of Iranian corn silk. Turkish J. Biol. 2008.32:43-9.

12. Egeblad M, Werb Z. New functions for the matrix metalloproteinases in cancer progression. Nat Rev Cancer. 2002.2:161e174.

13. Lekshmi Gangadhar and P. K. Praseetha, ANovel Modeling of Quantum Dot Sensitized Solar cells, Journal of Computational and Theoretical Nanoscience. 2019,Vol. 16, 389-392.

14. Lekshmi Gangadhar, Anusha Kannan and P. K. Praseetha ,Quantum Dot-Sensitized Solar Cells Via Integrated Experimental And Modeling Study, Journal of Computationaland Theoretical Nanoscience, 2019, Vol. 16, 436-440.
15. Lekshmi Gangadhar, AkhilaRajan, P. K Praseetha, Semiconductor Quantum Dots for Performance Improvement in Solar Cells, International Journal of Recent Technology and Engineering, 2019, Vol. 7, 11-17.

16. Fridovich I. Fundamental aspects of reactive oxygen species, or what's the matter with oxygen? Ann N Y Acad Sci. 1999.893:13-18.

17. Grabley, S., Thiericke, R., 1999. The impact of natural products on drug discovery. In: Drugs Discovery from Nature. Springer-Verlag, Berlin, pp. 1-37.

18. Gupta VK, Sharma SK. Plants as natural antioxidants. Nat Prod Radiance. 2006.5:326-34.

19. Halliwell B. How to characterize an antioxidant: an update. Biochem Soc Symp. 1995.61:73-101.

20. Hinneburg I, Damien Dorman HJ, Hiltunen R. Antioxidant activities of extracts from selected culinary herbs and spices. Food Chem. 2006 97:122-9.

21. Itoh $\mathrm{T}$, Tanioka $\mathrm{M}$, Yoshida $\mathrm{H}$, Yoshioka $\mathrm{T}$, Nishimoto $\mathrm{H}$, Itohara $\mathrm{S}$. Reduced angiogenesis and tumor progression in gelatinase A-deficient mice. Cancer Res. 1998.58:1048e1051.

22. Kalluri R, Zeisberg M. Fibroblasts in cancer. Nat Rev Cancer. 2006.6:392e401

23. Kaleem, S., Siddiqui, S., Siddiqui, H. H., Hussain, A., Arshad, M., Akhtar, J., \& Rizvi, A. (2016). Eupalitin induces apoptosis in prostate carcinoma cells through ROS generation and increase of caspase-3 activity. Cell biology international, 40(2), 196-203.

24. Kasibhatla, S., \& Tseng, B. (2003). Why target apoptosis in cancer treatment. Molecular cancer therapeutics, 2(6), 573-580.

25. Liu S-C, Yang S-F, Yeh K-T. Relationships between the level of matrix metalloproteinase-2 and tumor size of breast cancer. Clin Chim Acta. 2006.371:92e96.

26. Lobo V, Patil A, Phatak A, Chandra N. Free radicals, antioxidants and functional foods: impact on human health. Pharmacogn Rev. 2010.4:118-26.

27. Luis, A., Sandalio, L. M., Palma, J., Bueno, P., \&Corpas, F. J. (1992). Metabolism of oxygen radicals in peroxisomes and cellular implications. Free Radical Biology and Medicine, 13(5), 557-580.

28. Magder S. Reactive oxygen species: toxic molecules or spark of life? Crit Care. 2006.10:208-16.

29. Oyetayo V. 2009. Free radical scavenging and antimicrobial properties of extracts of wild mushrooms. Braz J Microbiol. 40:380-386.

30. Pimentel-Elardo, S.M., Kozytska, S., Bugni, T.S., Ireland, C.M., Moll, H., Hentsche, U., 2010. Anti-parasitic compounds from Streptomyces spp. strains isolated from Mediterranean sponges. Mar. Drugs 8 , 373-380.

31. Roy R, Yang J, Moses MA. Matrix metalloproteinases as novel biomarkers and potential therapeutic targets in human cancer. J Clin Oncol. 2009.27:5287e5297.

32. Soobrattee MA, Neergheen VS, Luximon-Ramma A, Aruoma OI, Bahorun T. Phenolics as potential antioxidant therapeutic agents: mechanism and actions. Mutat Res. 2005.579:200-13.

33. Sternlicht MD, Lochter A, Sympson CJ. The Stromal proteinase MMP3/Stromelysin-1 promotes mammary carcinogenesis 1999.98:137e146.

34. Tallant C, Marrero A, Gomis-Ruth FX. Matrix metalloproteinases: fold and function of their catalytic domains. BiochimBiophys Acta. 2010.1803:20e28.

35. Ueda J, Kajita M, Suenaga N, Fujii K, Seiki M. Sequence-specific silencing of MT1-MMP expression suppresses tumor cell migration and invasion: importance of MT1-MMP as a therapeutic target for invasive tumors. Oncogene. 2003.22:8716-8722.

36. Uhler, C., \& Shivashankar, G. V. (2018). Nuclear mechanopathology and cancer diagnosis. Trends in cancer, 4(4), 320-331.

37. Vihinen P, Kahari VM. Matrix metalloproteinases in cancer: prognostic markers and therapeutic targets. Int $\mathrm{J}$ Cancer. 2002.99:157e166.

38. Whittaker M, Floyd CD, Brown P, Gearing AJ. 1999 Design and therapeutic application of matrix metalloproteinase inhibitors. Chem Rev.99:2735e2776. 